\title{
GOOGLE'S CARS AND VISUAL RESISTANCE IN URBAN SPACE
}

\author{
Rafał Nahirny \\ University of Wrocław, Poland \\ rafal.nahirny@uwr.edu.pl
}

The article discusses how city residents react to the sight of Google cars taking pictures for the use of the Street View service? The author notes that the vast majority behaves completely normal as if the Google car was not even there. It is observed that some of the residents of the Street View world wave in a friendly manner towards the camera lens, some of them smile or take selfies with the vision machine passing by. However, there are some that opt for spontaneous gestures displaying displeasure at the presence of a nosy technology in their everyday space. The author creates an introductory typology of the methods of visual resistance and then proceeds with an analysis of specific strategies.

Keywords: Google Street View, urban space, vision machine, methods of resistance.

\section{АВТОМОБИЯИ GООGLЕ И ВИЗУАЛЬНОЕ СОПРОТИВ АЕНИЕ В ГОРОДСКОМ ПРОСТРАНСТВЕ}

\author{
Рафах Нагирный \\ Вроцлавский университет, Польша \\ rafal.nahirny@uwr.edu.pl
}

В статье исследуется, каким образом жители города реагируют на то, как автомобили Google фотографируют городское пространство для сервиса Street View. Автор отмечает, что подавляющее большинство ведёт себя совершенно нормально, как будто машины Google просто нет. Наблюдается, что некоторые жители дружелюбно машут в сторону объектива камеры, некоторые из них улыбаются или делают селфи с проезжающей мимо «машиной зрения». Однако есть некоторые жители, которые предпочитают спонтанные жесты, демонстрирующие недоводьство присутствием дюбопытных технологий в их повседневном пространстве. Автор создаёт и предлагает начальную типодогию методов визуального сопротивления, а также анализирует его конкретные стратегии.

Кдючевые слова: Google Street View, городское пространство, машина зрения, методы сопротивления.

DOI 10.23951/2312-7899-2019-2-33-41 
One day, without any prior warning, Google vehicles appeared on the streets of the city where I live. The news of them spread like gossip. An older brother of one of my colleagues assured us that he saw with his own eyes how they "drove around and took pictures". Some of the residents hypothesized that perhaps the presence of the Google cars had some sort of connection to the Euro 2012 for which Wrocław was one of the host cities. This event did not go unnoticed by the local newspapers: "Google car photographs Wrocław (PHOTOS)"1. In accordance to the headline, a gallery for the online edition of one of the newspapers showed the Google car in various spots of the city, taking pictures of Wrocław. The journalists informed the public that - thanks to Google Street View - one can take a tour of cities such as Prague or Berlin without ever leaving the house. Soon Wrocław was to be a part of this elite group of cities. A few days later I saw a Google vehicle as it slowly made its way between the cars parked on a narrow, one-way street of my housing estate. The distinctive car with nine eyes on its roof moved slowly and persistently towards the bakery where I have been buying bread since childhood. I remember seeing this and feeling baffled. Why would some gigantic Silicon Valley multinational take interest in a small family bakery on the other side of the world? In my visual imagination places worth of visitors' interest were places of historical importance such as the city hall, the cathedral or the Centennial Hall. I saw them dozens of time not only with my own eyes but also on the postcards, calendars and covers of tourist guidebooks. Meanwhile, in my everyday life I did not see any tourist attractions worth of taking pictures. In this regard the Google vehicle resembled the participants of German nostalgic trips to Breslau of pre-WWII times that would visit city spots rarely frequented by ordinary tourists. I could understand a practical approach - for example a project of photographing the route from the airport or bus terminal to the football stadium; meanwhile, the Google car found itself exactly on the other side of the city, as far from the stadium where Euro 2012 was supposed to take place as possible. The trackers of the new digital world seemed incredibly determined to reach the "U Zbyszka" bakery. For some reason, a group of programmers, engineers and investors decided that the everyday reality of Wrocław citizens had something valuable, interesting and worth preserving with the use of refined vision technology. And so Google vehicles photographed other important points of interests of my small world - a bus stop, a newsstand or a stand with vegetables and fruits. The time came

\footnotetext{
${ }^{1}$ Relikowski P. Auto Google fotografuje Wrocław (ZDJĘCIA). Gazetawroclawska.pl. 2011. June 30. URL: https://gazetawroclawska.pl/auto-google-fotografuje-wroclaw-zdjecia/ar/421363\#wiadomosci.
} 
to a halt and I could take a trip back in time and see the how the world looked like 10 years ago without leaving my desk.

The nosy gaze of the technological giant did not cause significant anxieties and controversies back then. A large part of Wrocław citizens felt appreciated by the Silicon Valley interest. Our city became worthy of attention and Google's gaze was supposed to make it a part of the new digital modern times suitable for the broadly defined Western world. The presence of the advanced vision machines [Virilio 1994] in the urban space healed the post-communist insecurities to some extent. Not many treated it as something suspicious and requiring critical consideration. It was not a form of visual violence but rather an affirmative gesture of approval foretelling the creation of a new intelligent city filled with digital technologies ${ }^{2}$.

While in the past agents of colonial powers would take over the "discovered" lands by symbolically raising their national flag, nowadays the new technological empires colonize the space of everyday life in a different way. Out of nowhere, Google Street View vehicles show up in the city streets in accordance with the logic of creative disruption. Sometimes the competing empires encounter each other's expeditions. In a city of Plymouth, Minnesota the Google car bumped into the Microsoft vehicle. The giant from Redmond, inspired by the Street View, launched its analogical service called StreetSide as part of the Bing map. For a moment, the drivers of both cars could feel like the city residents they were photographing. On a picture published on Bing you can clearly see the Google employee waving in a friendly manner towards the competition. What is interesting is that initially Microsoft literally deleted the rival's car from their world. In place of the Google car one could only see a white rectangle - a distinctive sign of photo editing in a graphic program. Only after the tech press became interested in the unusual meeting was the photo of the Google driver waving restored ${ }^{3}$.

With the help of Google Street View we can partake in a sentimental trip down memory lane to the times of their childhood and view on a screen pictures of spaces to which we are emotionally connected or even take a walk through alleys where we played with our friends. The presence itself of the Google car has, however, an imperial meaning

\footnotetext{
2 Today citizens of Polish cities show much stronger criticism against technological forms of disturbing the urban space by companies from the Silicon Valley. Electric scooters, which similarly to Google vehicles, suddenly appeared in the urban space, using legal loopholes and lack of regulation in electro-mobility, quickly became a topic of public debate. Authorities of some cities even pick up the scooters lying on sidewalks and bicycle routes as abandoned property.

${ }^{3}$ URL: https://www.google.com/maps/@45.0416709,-93.462387,3a,75y,77.03h,82.03t/data=!3m6!1e1!3 m4!1s-LeELqjYFFSYqTZJkCNYTw!2e0!7i13312!8i6656.
} 
as well. The pictures that form the world of the Street View allow for nostalgic voyages or finding hints that will help us reach the trip destination - but at the same time they tell its viewers something else: "Nothing will hide from our sight. We will reach even those small, lost and forgotten alleys and backstreets on the outskirts of your cities and towns that are not interesting for tourists".

This way, with the use of tracking media and gigantic databases, a new digital world came to life - a visual map that aims at recreating the real world in almost 1:1 scale. Satellite pictures of the urban space taken from the divine perspective along with a city-level photography and 3D modeling technology create a total image of the city [Hoelzl, Marie 2015, 91]. The authorities, in accordance with the panoptical logic of visual practicality, are supposed to be invisible and unverifiable [Foucault 2012]. The similar can be observed in the Street View world. The user sees the city from the perspective of Google's nine eyes. The vision machine itself, responsible for the creation of this world, remains hidden. That is why members of the F.A.T. Lab, as a part of the Transmediale 2010, built their own Google car - a faithful copy of vehicles used by the technological giant. A proper car model, car paint and distinctive labels on the car body were chosen; then a mock-up construction resembling the system of lenses and scanners was constructed on the hood of the vehicle. Sometimes, however, the vision machine reveals its presence by itself. It happens when a Google vehicle passes by a shop window, road mirrors or mirrors left by the trash. It photographs itself in that moment, creating an accidental self-portrait.

Not every citizen of the Street View world is pleased with the fact that they have become a part of a hybrid, panoptical reality. Civil methods of resistance against the Google project take various forms. Protests or even blockades are organized. Some of the activists deceitfully use the Google Map service for group mapping of Google vehicles and their localization in the urban space 4 . In this article I will focus solely on small gestures of visual resistance that were pictured by the Google cameras.

The Street View world in the eyes of Michael Wolf, a famous German photographer that has been interested in the urban space for years, is a gigantic photographic archive. Due to peculiar nature of this collection, browsing it resembles taking a walk. This way the archive created by Google becomes a visual environment, a new photographic eco-system which artists like Wolf or Jon Rafman, Doug Rickard or Mishka Henner traverse in search of critical moments of the digital society. Such

\footnotetext{
${ }^{4}$ URL: https://www.google.com/maps/d/viewer?ie=UTF8\&oe=UTF8\&msa=0\&mid=1i_WX7MR85o M_If0eNAgi8bxXy4w\&ll=48.36341130460681\%2C8.228129499999909\&z=4.
} 
voyeuristic huntings turn into exercise in not only frame composition, but also investigative skills. Google cars often become witnesses of scenes which can be hard to grasp when it comes to their meaning. A lot of pictures found in the Street View world may effectively confuse the viewer: a baby crawling in front of the Gucci store without any supervision; a man exiting a trunk of a car parked in a driveway of some villa; a man lying on the street with his head against the curb. Are all of those pictures a result of some spontaneous performances hastily organized at the sight of an oncoming Google car or did the vision machine bear witness to some deeply disturbing event taking place?

Wolf did not stop at appreciating accidental beauty; he could have limited himself to taking screenshots, yet he took pictures of a fragment of Street View world shown on the monitor with the use of traditional photo camera. On the one hand, this seemingly superfluous gesture depicts the aura of the digital images. One can clearly see every monitor pixel on the pictures, similar to the analogue camera grain. The aesthetics of noise and disturbances is suitable for the digital visual culture of the Internet. Pictures that are copied and republished in social media are subjected to gradual and inevitable pixelization and become poor images [Steyerl 2009]. Such effect is intensified by the fact that the photographs constituting the Street View world are purposefully taken in low resolution. On the other hand, Wolf seems to humanize the authorless mechanical photography that was completely subjected to practicality. The Google gaze is not the same as the artist's perspective. This way the images establishing a part of photographic stream registered by the vision machines show their aesthetic potential.

A distinct feature of the projects realized by Wolf in the Street View world is arranging the pictures in photographic series. One of the German artist's collections is titled in a rather telling way: "Fuck You" Pictures presented in that series depict people making a distinctive gesture: a raised hand with a middle finger lifted up, usually aimed in the direction of the Google car passing by. Not much is known about the people in Wolf's pictures. Sometimes they drive a car, other times they ride a bicycle; it is impossible to determine the place where the pictures were taken. However, the basic meaning of the gestures found by Wolf is clear without the local cultural context. Here one can observe a spontaneous and anonymous international coalition of the middle finger provoked to perform an unkind prank by the presence of the Google vehicle in the everyday urban space.

${ }^{5}$ Wolf M. Street View. Fuck You. URL: http://photomichaelwolf.com/\#fuck-you/1. 
Additionally, the intensity of the gesture was increased by Wolf himself, who framed all the pictures in the series in a very specific way he made the people throwing the obscene gesture at Google vehicles the central element of every picture. Nothing else can be seen other than the main 'characters' of the photos - they were consistently isolated from the context created by the technological gaze. As a result, a series of frontal portraits was made that can be described as "stolen portraits" due to the lack of permission from people pictured in the photos by Google/Wolf [Hoelzl, Marie 2015, 87].

Who, however, is insulted in this matter? The vehicle's driver? Surely the recipient of the gestures registered by Wolf was mainly the anonymous corporation whose nosy trackers suddenly appeared in the living space of the people in those photos. The supporting evidence is the fact that the hand portrayed by Wolf is raised high in the direction of the photo cameras and the LIDAL laser. The recipient of this gesture was, above all, the machine, not the man controlling it. Nevertheless, quite unexpectedly, the viewer's look coincides with the gaze of the technological giant, which may embarrass them - as if the pictured were telling the viewer that they were not supposed to be there and there was nothing there for them; that they should go back to where they came from as soon as possible.

From time to time the methods of resistance against the technological gaze of the Silicon Valley take a more radical form. In the Street View world you can encounter residents that throw objects at the Google car passing by; random objects found at hand are flying towards the camera - soda bottles or flip flops. An intruder showing up causes the everyday objects to turn into tools of resistance. The Google cameras also happened to record even more radical forms of visual resistance in some of the photos we can see people getting naked in front of the car passing by them. And so one can see bare buttocks aimed at the advanced technological vision machines; sometimes there are naked female breasts. People in those photos are clearly amused with their act and the aura emanating from them has a lot in common with crude, physical comedy [Critchley 2002] resulting from a conscious transgression of ordinary norms of behaving in public space. Are those exhibitionistic forms of shamelessness supposed to embarrass the future users? Google assumes that the users will be using their service in order to achieve practical hints that will help them reach their point of destination. Someone has bought furniture on the Internet and is now looking for a parking spot so that they will not have to carry the desk far. Someone else is checking the exact location of the new place their friends 
rented before going there. One can imagine the moment when suddenly their eyes meet the shamelessly naked buttocks or breasts. Such indecent sight in public space would probably perplex a lot of people.

Does this mean that people making juvenile jokes with their bodies in the world of Street View are setting traps for the innocent users? Do they want to disgust someone out of nowhere? The Greek word "scand-

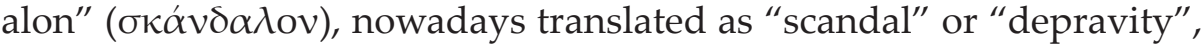
in biblical times also meant "an obstacle", "a trap" or "a stone" over which one can trip. By this meaning the Street View users are literally tripping over images of naked breasts or buttocks while walking through the world of Street View. The rules of discretion protect the individual against the nosy looks of others; the participants of the social life restrain themselves from insistent infiltration into other people's private lives. It is not in good taste to eavesdrop under somebody's doors or go through private mail inboxes of their own friends. According to the commentary by Georg Simmel [Simmel 2008], discretion protects the onlookers against the affront of indiscretion. The comedy of crude bodies of homo ludens thus violates the privacy of the viewers.

It is not the first time when naked bodies in public space have become the tool of political resistance in the times of liquid surveillance [Bauman, Lyon 2012]. John Brennan stripped naked during the standard control at the Portland airport to prove that he does not carry any explosives and at the same time protest against too meticulous procedures that take form of harassment aimed at ordinary citizens. Brennan felt especially provoked and humiliated by a remark made by one the TSA agents who suggested that he might be a terrorist.

The creators of the Street View world understandably try to protect their users and censor any forms of nudity in the public space - any buttocks or breasts are thus tracked down and then blurred out, more or less competently. The blurring is also applied to the faces of dwellers of the Street View world, as a result of the controversies concerning the privacy and protection of own image, namely the right to record and publish it in the media. It is not, however, a perfect solution - you can still successfully identify specific people which often means trouble for the photographed individuals. The face and nudity blurring is a visual method known most commonly from the public media, such as the press and the TV - this way journalists and editors protect the identities of suspects or people apprehended by the police or other security forces. The act of blurring is a part of this aesthetic; hence, creating a new, criminal association with the acts of the disobedient citizens in the Street View world [Hoelzl, Marie 2015, 88]. 
How one is supposed to interpret all those forms of visual resistance? Is showing the middle finger, your naked buttocks or throwing an object in the direction of a passing Google vehicle a sign of helplessness against the new prying and ubiquitous technologies? The trackers of the digital capitalism show up - usually uninvited - in the everyday space. Caught by the panoptical Google sight, the citizens of the Street View world did not get a chance to voice their objections. A lot of them hide their faces, turn their backs against the camera, crouch behind the hedgerows or hide behind the elements of the urban infrastructure. All those acts are aimed at hindering the identification of people shown in the picture. Meanwhile the people described above use much more active forms of resistance. From Google's perspective the residents of the Street View world are only a source of trouble - they do not provide any practical information for the users searching for travelling hints. They are redundant elements of decoration that, as a matter of fact, have no need to exist. That is why the forms of resistance described above can be interpreted as acts of refusal to participate in the spectacle where the roles have already been defined. People showing the middle finger, stripping naked or throwing objects at the Google cameras seem to reject the role of passive bystanders in the project of the Silicon Valley giant. The spontaneous acts of resistance become a part of the total image of the city.

Acts of visual sabotage taken up by the insubordinate citizens of the Street View world fit into the category of photo bombing. It can be a deliberate action - a ludic and carnivalesque visual act - but it may also be something achieved by accident. A person making a gesture or a face - but also an animal or even an inanimate object - can disturb the whole composition with their presence and become the photo bombers while capturing the viewer's attention. Hence, the meaning of the picture created by the authors and the main subject of the photograph is disrupted [Fletcher, Greenhill 2010; Ibrahim 2017]. Such unexpected intrusion usually creates a comedic effect in those images. As Yasmin Ibrahim notes - the term "bomb" itself suggests a radical act of disintegration. Thus it is not a small detail that requires an eagle eye; the scale of destruction is visible at first glance. Photo bombing, understood as a visual act, created a whole separate genre of vernacular photography (with the help of websites such as thisisphotobomb.com).

People in the portraits taken by Wolf, rather than wave in a friendly manner at the Google car, take a selfie with it or act like it is not even there, introduce rebellious elements that do not fit into the organized and functional space of the Street View world. The subversive forms 
of vulgarity, vandalism and obscenity destroy images that meant so much to the technological giant. The registered photographs become "undisplayable" and thus lose their strictly functional nature.

\section{REFERENCE}

Bauman, Lyon 2012 - Bauman Z., Lyon D. Liquid Surveillance: A Conversation. Cambridge, Malden, 2012.

Critchley 2002 - Critchley S. On Humour. London, 2002.

Fletcher, Greenhill 2010 - Flechter G., Greenhill A. Photobombing: Mobility, Humor and Culture. Proceedings Cultural Attitudes Towards Communication and Technology. Ed. by F. Sudweeks, H. Hrachovec, C. Ess. Murdoch, 2010. P. 198-206.

Foucault 2012 - Foucault M. Discipline and Punish: The Birth of the Prison. Transl. into English by A. Sheridian. New York, 2012.

Hoelzl, Marie 2015 - Hoelzl I., Marie R. Softimage: Towards a New Theory of the Digital Image. Bristol, Chicago, 2015.

Ibrahim 2017 - Ibrahim Y. The Vernacular of Photobombing. The Aesthetics of Transgression. Convergence: The International Journal of Research into New Media Technologies. 2017. November 27. URL: https://journals.sagepub.com/doi/10.1177/1354856517743666

Simmel 2008 - Simmel G. Psychologia dyskrecji. Transl. into Polish by M. Łukasiewicz. Simmel G. Pisma socjologiczne. Ed. by H.-J. Dahme, O. Rammstedt. Warszawa, 2008. P. 174-181.

Steyerl 2009 - Steyerl H. In Defense of the Poor Image. E-Flux. 2009. № 10. URL: https://www.e-flux.com/journal/10/61362/in-defense-ofthe-poor-image/

Virilio 1994 - Virilio P. The Vision Machine. Transl. into English by J. Rose. Bloomington, 1994. 